\title{
Pengembangan Permainan Edukasi Etiket Perjamuan Makan Berbasis Web
}

\author{
Bella Tashia ${ }^{1)}$ Alexander Waworuntu ${ }^{2)}$ \\ Informatika, Institut Teknologi dan Bisnis Kalbis \\ Jalan Pulomas Selatan Kav. 22, Jakarta Timur, 13210 \\ ${ }^{1)}$ Email: bellatashia@gmail.com \\ ${ }^{2)}$ Email: alex.wawo@kalbis.ac.id
}

\begin{abstract}
The purpose of this research is to produce a web-based western table manners etiquette education game. This game is developed to give an alternative solution for society to learn about western table manners. The technology uses to develop this game is a web-based technology. This research uses Game Development Life Cycle method. The development requires some languages such as HTML, CSS, Javascript, AJAX, and PHP language. Researcher utilizes Bootstrap framework and JQuery to create a responsive view of this game. The game's data will be stored on MySQL database. The final result of this research is an educational game which can be accessed by users using their browser application from any devices which have been connected to internet network. Users can be able to learn about western table manners' etiquette rules virtually by using this game.
\end{abstract}

Keywords: educational game, Game Development Life Cycle, Javascript, Web, Western culture

\begin{abstract}
Abstrak: Tujuan penelitian ini menghasilkan sebuah permainan edukasi etiket perjamuan makan budaya Barat berbasis web. Permainan edukasi ini dikembangkan untuk memberikan solusi atas kurangnya pengetahuan masyarakat awam atas pendidikan etiket perjamuan makan budaya Barat. Teknologi yang digunakan untuk mengembangkan permainan ini adalah teknologi berbasis web. Metode yang digunakan untuk mengembangkan permainan ini adalah metode Game Development Life Cycle. Permainan ini dikembangkan dengan menggunakan bahasa HTML, CSS, Javascript, AJAX, dan PHP. Framework Bootstrap dan JQuery juga digunakan untuk menciptakan tampilan yang responsif. Sistem basis data MySQL juga digunakan untuk menyimpan sebagian data permainan. Hasil akhir dari penelitian ini adalah permainan edukasi yang dapat diakses oleh pengguna melalui aplikasi browser (peramban) pada berbagai perangkat yang sudah terhubung ke internet. Dengan memainkan permainan ini, pengguna dapat mempelajari beberapa aturan dasar mengenai etiket perjamuan makan budaya Barat secara virtual.
\end{abstract}

Kata Kunci: budaya Barat, Game Development Life Cycle, Javascript, permainan edukasi, Web

\section{PENDAHULUAN}

Table manners atau fine dining etiquette (etiket perjamuan makan) merupakan kumpulan tata cara makan yang harus dipatuhi ketika menghadiri jamuan makan resmi atau formal, baik di hotel atau pun restoran. Etiket perjamuan makan resmi tentu berbeda dengan etiket perjamuan makan keluarga, dimana biasanya etiket resmi mengusung tema kebudayaan makanan tertentu. Salah satu etiket yang digunakan secara internasional adalah etiket kebudayaan Barat [1]. Di Indonesia, etiket perjamuan makan resmi tidak menjadi mata pelajaran wajib. Pelajaran ini dapat dipelajari melalui pendidikan resmi, seperti melalui sekolah kejuruan dan kuliah jurusan Perhotelan. Jalur pendidikan lain yang dapat ditempuh adalah kursus dan sertifikasi di hotel atau restoran tertentu dengan biaya yang terbilang cukup mahal. Hal ini menyebabkan banyak masyarakat Indonesia yang belum mengetahui etiket perjamuan makan yang benar. Ketika mereka belum mengetahui pengetahuan dasar terkait tata sikap dan perilaku, maka mereka dapat melakukan beberapa kesalahan umum ketika menghadiri jamuan makan. Kesalahan tersebut dapat membuat mereka dianggap tidak sopan oleh tuan rumah atau tamu jamuan lain.

Berdasarkan permasalahan kurangnya pengetahuan akan tata sikap dan perilaku tersebut, peneliti memutuskan untuk mengembangkan media pelengkap pembelajaran mengenai etiket perjamuan makan budaya Barat. Bentuk media pembelajaran yang peneliti pilih adalah permainan edukasi berbasis teknologi web. Teknologi web dipilih agar pengguna dapat mengakses permainan dari berbagai jenis perangkat tanpa harus melakukan instalasi yang membebankan memori perangkat. Pengguna 
hanya perlu terkoneksi dengan jaringan internet, lalu mengaksesnya dari aplikasi peramban tertentu.

Permainan ini dikembangkan menggunakan bahasa HTML, CSS, Javascript, AJAX, dan PHP. Peneliti juga menggunakan framework Bootstrap dan library JQuery untuk menciptakan tampilan yang responsif. Obfuscation juga digunakan untuk mengamankan kode Javascript, sehingga fungsi Javascript yang penting tidak mudah dibaca oleh pengguna [2]. Basis data MYSQL juga turut digunakan untuk menyimpan hasil Polling.

Peneliti terinspirasi dari acara kuis televisi “Who Wants To Be a Millionaire?". Konsep acara ini adalah pemain akan dihadapkan dengan serangkaian pertanyaan berbentuk pilihan ganda yang harus dijawab dengan benar berdasarkan milestone yang tersedia [3]. Pemain harus berhasil menjawab pertanyaan denggan benar untuk mendapatkan hadiah. Pemain diberikan tiga pilihan bantuan yang masing-masing hanya dapat digunakan sekali selama permainan berlangsung. Ask Audiences merupakan bantuan yang memungkinkan pengguna melihat persentase pilihan jawaban penonton. 50:50 merupakan bantuan untuk menghilangkan dua pilihan jawaban yang salah. Phone a Friend merupakan bantuan yang memungkinkan pengguna untuk bertanya kepada kerabat melalui sambungan telepon.

Tujuan penelitian ini adalah menghasilkan permainan edukasi etiket perjamuan makan budaya Barat bagi semua kalangan, tanpa terbatas jenis kelamin, usia, atau pun ras. Ada pun manfaat yang diberikan adalah menjadi media pelengkap pembelajaran bagi masyarakat, selain jalur pendidikan resmi, yang dapat dipelajari sebelum mereka menghadiri jamuan makan. Manfaat lain yang diberikan adalah memberikan pengetahuan dasar terkait tata sikap dan perilaku yang baik dan benar dalam etiket perjamuan makan budaya Barat.

\section{METODE PENELITIAN}

\section{A. Penelitian Sebelumnya}

Penelitian pertama berjudul "Aplikasi Game Edukasi Petualangan Nusantara" yang dikembangkan oleh Arifiati Fitri Anggraini, Nena Erviana, Sofiya Anggraini, dan Didik Dwi Prasetya [4]. Penelitian ini dikembangkan dengan metode ADDIE, yaitu Analysis, Design, Development, Implementation, dan Evaluation. Hasilnya adalah permainan anak-anak berbasis mobile Android yang berupa petualangan mencari benda-benda adat Indonesia. Penelitian kedua berjudul "Pengembangan Permainan Video
Endless Running Berbasis Android Menggunakan Framework Game Development Life Cycle" yang dikembangkan oleh Rendy Adiwikarta dan Harya Bima Dirgantara [5]. Penelitian ini dikembangkan dengan metode Game Development Life Cycle. Hasilnya adalah permainan endless running berbasis mobile Android yang bertujuan untuk melatih reflek pengguna. Penelitian ketiga berjudul "Online Game "Pics and Words" sebagai Media Edukasi Bahasa Inggris Berbasis HTML" yang dikembangkan oleh Edy Budiman, Rofilde Hasudungan, dan Akhmad Khoiri [6]. Penelitian dikembangkan dengan metode ADDIE. Hasilnya adalah permainan berbasis web yang mengharuskan pemain untuk menebak dan menyusun huruf dalam bahasa Inggris.

\section{B. Permainan Edukasi}

Permainan edukasi merupakan permainan yang dikembangkan untuk mengubah cara pembelajaran menjadi lebih menarik dan menyenangkan, sehingga lebih mudah dipahami [4]. Salah satu genre permainan yang peneliti gunakan pada penelitian ini adalah genre arcade. Genre arcade adalah jenis permainan yang mengharuskan pemain melewati rintangan tertentu untuk mencapai tujuan. Pemain harus mengumpulkan koin atau poin untuk mendapatkan bantuan. Contoh permainannya adalah "Who Wants To Be a Millionaire?" [3].

\section{Web}

Web merupakan teknologi penyebaran informasi yang dapat memuat berbagai konten dan dapat diakses melalui jaringan internet [7]. Beberapa bahasa pemrograman yang digunakan di dalam penelitian ini dapat dilihat pada Tabel 1.

\section{Basis Data}

Basis data adalah proses pengelompokkan datadata ke dalam suatu tabel secara terkomputerisasi, sehingga dapat menghindari ketidakkonsistenan dan duplikasi data. Salah satu contoh Database Management System (DBMS) yang sering digunakan adalah MySQL [12]. MySQL merupakan sebuah perangkat lunak DBMS yang menyimpan data dalam tabel relasional yang saling terhubung [13]. MySQL menggunakan bahasa query untuk mengolah data dalam tabelnya.

\section{E. Obfuscation}

Obfuscation merupakan tindakan untuk mengubah kode pemrograman menjadi kode mesin yang sulit dipahami oleh manusia. Kode yang 
Tabel 1 Bahasa Pemrograman yang Digunakan

\begin{tabular}{|c|c|}
\hline Nama & Deskripsi \\
\hline $\begin{array}{l}\text { Hyper Text Markup } \\
\text { Language (HTML) }\end{array}$ & $\begin{array}{l}\text { Sebuah bahasa yang dapat } \\
\text { digunakan untuk } \\
\text { mengembangkan sintaks } \\
\text { dan kode-kode web [7] }\end{array}$ \\
\hline $\begin{array}{l}\text { Cascading Style Shest } \\
\text { (CSS) }\end{array}$ & $\begin{array}{l}\text { Sebuah bahasa yang dapat } \\
\text { digunakan untuk } \\
\text { mengembangkan tampilan } \\
\text { sebuah wob [8] }\end{array}$ \\
\hline Javascript & $\begin{array}{l}\text { Sebuah bahasa } \\
\text { pemrograman yang dapat } \\
\text { digunakan untuk } \\
\text { mengembangkan skrip } \\
\text { sintaks berbasis objek [9] }\end{array}$ \\
\hline Librayy JQuery 3.3.1. & $\begin{array}{l}\text { Memungkinkan agar } \\
\text { pembuatan kode fungsi } \\
\text { atau gintaks Javascript } \\
\text { menjadi lebih gingkat [10] }\end{array}$ \\
\hline Bootstrap 4.0.0. & $\begin{array}{l}\text { Sebuah framework berupa } \\
\text { file .css dan .js yang } \\
\text { digunakan untuk } \\
\text { mengembangkan halaman } \\
\text { web yang lebih responsif, } \\
\text { sehingga dapat } \\
\text { menyesuaikan ukuran layar } \\
\text { perangkat [11] }\end{array}$ \\
\hline $\begin{array}{l}\text { Hypertext Preprocessor } \\
\text { (PHP) }\end{array}$ & $\begin{array}{l}\text { Bahasa pemrograman } \\
\text { berbentuk skrip yang } \\
\text { berada di sisi senver [8] }\end{array}$ \\
\hline $\begin{array}{l}\text { Asynchronous Javascript } \\
\text { and XML (AJAX) }\end{array}$ & $\begin{array}{l}\text { Kombinasi antara } \\
\text { Javascript, XHTML, CSS, } \\
\text { konsep DOM, permintaan } \\
\text { HTTP, dan XIIL untuk } \\
\text { menciptakan web yang } \\
\text { lebih responsif [7] }\end{array}$ \\
\hline
\end{tabular}

diubah adalah bentuk teks string, nama fungsi, dan nama variabel. Obfuscation dapat digunakan untuk menyembunyikan logika pemrograman dan informasi penting yang dicantumkan di dalam source code. Fungsi lain dari obfuscation adalah meminimalkan ukuran file dengan menghapus baris kosong dan mengubah nama variabel yang digunakan pada kode pemrograman. Hal ini dapat membuat proses transfer data dari server ke klien menjadi lebih cepat [2]. Ketika file obfuscation dipanggil oleh server, file dapat langsung dieksekusi tanpa memerlukan proses lain, karena kode sudah diubah ke bentuk bilangan heksadesimal dari UTF-8 yang merupakan kode mesin. Kode obfuscation dapat dibuat baik secara manual atau dengan memanfaatkan tools. Salah satu tools obfuscation yang peneliti gunakan adalah Obfuscator Javascript yang dapat diakses melalui situs https://javascriptobfuscator.com.

\section{F. Pemodelan Prototipe}

Pemodelan prototipe merupakan salah satu metode penggambaran perangkat lunak yang memungkinkan pengguna untuk melihat dan menguji sebagian dari perangkat lunak yang akan dibuat [14].
Salah satu model pemodelan prototipe yang digunakan peneliti adalah model paper prototype. Paper prototype, yaitu model prototipe yang memanfaatkan bentuk diagram untuk memberi gambaran mengenai interaksi antara perangkat lunak dan pengguna. Jenis ini digunakan dalam penelitian yang peneliti lakukan.

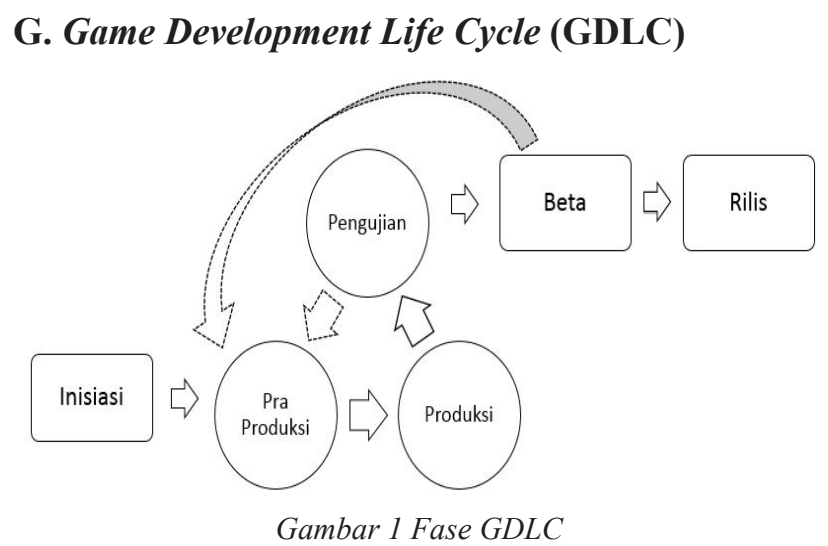

Pada penelitian ini, model GDLC yang digunakan adalah proposed GDLC. Fase-fase GDLC terdiri atas 5 fase seperti yang terdapat pada Gambar 1. Fase inisiasi merupakan tahap penciptaan konsep dasar mengenai permainan yang akan dikembangkan. Fase pra produksi merupakan tahap penciptaan desain utuh yang merupakan lanjutan dari konsep dasar yang sudah dibuat serta pembuatan rancangan prototipe. Fase produksi merupakan tahap pengembangan kode pemrograman untuk permainan sampai dengan selesai. Fase pengujian merupakan tahap uji coba yang dilakukan oleh pihak pengembang ketika seluruh kode selesai dibuat, namun permainan belum dirilis secara resmi ke pengguna. Fase beta merupakan tahap pengujian lanjutan yang dilakukan oleh pengguna. Jika pada fase pengujian atau pada fase beta masih ditemukan ketidaksesuaian hasil atau perubahan permintaan terhadap permainan, maka peneliti harus melakukan tahap iterasi ke fase pra produksi seperti pada gambar 1. Fase rilis merupakan tahap akhir dalam pengembangan permainan. Hasil akhir dari fase ini adalah dokumentasi dan permainan yang akan dirilis ke pengguna secara resmi sesuai dengan platform yang dituju. Permainan yang dirilis merupakan versi yang sudah lulus uji dan layak untuk digunakan oleh pengguna [15].

\section{H. Black Box Testing}

Black box testing adalah salah satu jenis pengujian perangkat lunak yang dilakukan dengan cara menguji apakah berbagai masukkan sesuai dengan hasil keluaran. Penguji hanya perlu menguji fungsionalitas, mengidentifikasi, dan memverifikasi hasil keluaran, apakah hasilnya valid atau tidak [16]. 


\section{HASIL DAN PEMBAHASAN}

\section{A. Kerangka Pemikiran}

Pada masa pra penelitian, peneliti melakukan observasi dan kajian pustaka untuk mengidentifikasi masalah yang ada. Hasil observasi yang didapat adalah bahwa masyarakat awam kurang begitu mengetahui teori dasar tata sikap dan perilaku dalam perjamuan makan budaya Barat. Kesalahan sikap dan perilaku akibat ketidakpahaman terhadap pengetahuan ini menyebabkan tamu undangan dianggap tidak sopan oleh tuan rumah, sehingga peneliti memutuskan untuk mengembangkan sebuah media pelengkap pembelajaran bagi mereka. Hasil kajian pustaka dari teori-teori dan penelitian sebelumnya telah memberikan ide kepada peneliti untuk mengembangkan sebuah permainan edukasi teori dasar tata sikap dan perilaku etiket perjamuan makan budaya Barat berbasis web.

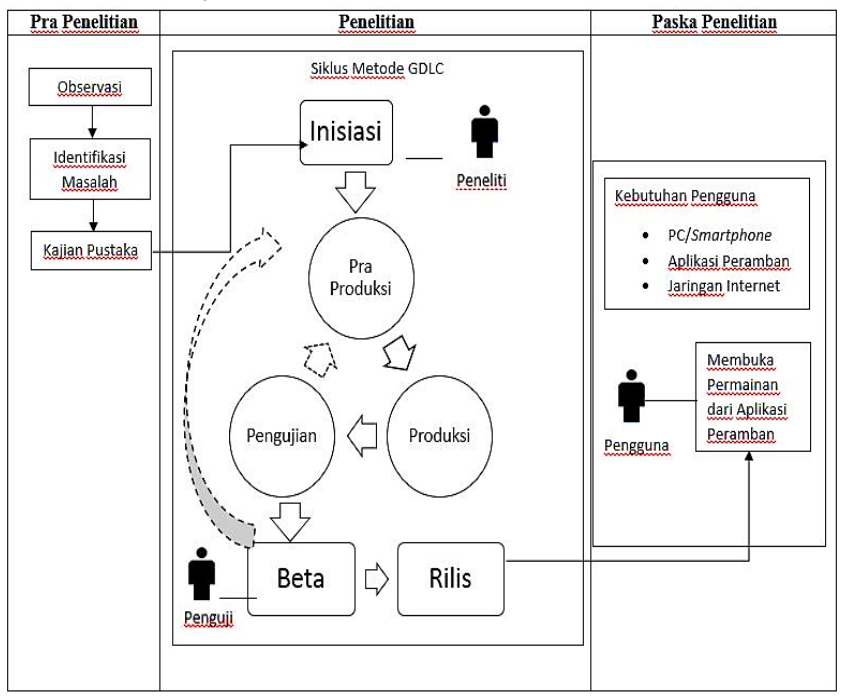

Gambar 2 Kerangka Pemikiran

Selama proses penelitian berlangsung, peneliti menggunakan metode proposed GDLC menurut Widyani dan Ramadan dengan fase seperti yang terdapat pada Gambar 2. Pada fase inisiasi, peneliti merancang konsep dasar dan membuatnya dalam bentuk deskripsi singkat. Setelah itu, peneliti akan merumuskan alur permainan serta merancang desain permainan pada fase pra produksi. Permainan akan dibuat dengan menggunakan bahasa pemrograman sampai selesai. Setelah permainan selesai dikembangkan, permainan akan melalui beberapa pengujian untuk menguji kesesuaian dan kelayakannya. Setelah pengujian selesai atau pada masa paska penelitian, permainan akan dirilis ke pengguna dalam bentuk web yang dapat diakses melalui berbagai perangkat yang sudah terhubung ke jaringan internet. Pengguna hanya perlu memasukkan alamat situs web ke aplikasi peramban/pencari yang mereka miliki.

\section{B. Inisiasi}

Konsep dasar permainan ini terinspirasi dari acara kuis televisi “Who Wants To Be a Millionaire?". Pemain akan dihadapkan dengan beberapa pertanyaan berbentuk pilihan ganda, dimana terdapat empat pilihan jawaban yang harus dipilih salah satunya. Pertanyaan yang disajikan terkait pengetahuan seputar etiket perjamuan makan budaya Barat yang harus dilakukan ketika menghadiri sebuah perjamuan makan formal di hotel atau restoran. Urutan pertanyaan dan jawaban dari setiap titik aman akan diacak agar tidak mudah ditebak oleh pemain. Jika pemain berhasil menjawab dengan benar dalam waktu 20 detik, maka pemain akan menerima 100 poin dan dapat melanjutkan ke pertanyaan selanjutnya. Seluruh pertanyaan tersebut akan terbagi ke dalam lima level titik aman, dengan tingkat pertanyaan dari yang termudah sampai tersulit. Setiap level memiliki skor titik aman yang berbeda, yaitu 0, 100, 500, 1500, dan 2000. Selama permainan, jika pemain merasa kesulitan dalam menjawab pertanyaan, mereka juga mendapat beberapa pilihan bantuan berupa Menyerah, 50:50, dan Bocoran. Masing-masing bantuan hanya dapat digunakan sekali selama permainan, sehingga setelah tombol bantuan digunakan, maka tombol akan disembunyikan atau dihilangkan.

Selama pengembangan penelitian ini, peneliti dan pengguna membutuhkan perangkat Android versi 5 (Lollipop) ke atas dan desktop Windows. Perangkat tersebut harus terhubung dengan jaringan internet dan memiliki beberapa browser (aplikasi peramban) tertentu. Aplikasi peramban yang disarankan untuk digunakan dapat dilihat pada Tabel 2. Semua aplikasi peramban tersebut harus merupakan versi terbaru agar dapat mendukung tag Bootstrap, sehingga tampilan web-nya tetap responsif.

Tabel 2 Aplikasi Peramban yang Disarankan

\begin{tabular}{ll}
\hline \multicolumn{1}{c}{ Desktop Windows } & \multicolumn{1}{c}{ Android } \\
\hline Google Chrome & Google Chrome \\
Mozilla Firefox & Mozilla Firefox \\
Opera & Microsoft Edge \\
Intemet Explorer v10+ & Android Browser \& Web \\
& View \\
\hline
\end{tabular}

\section{Pra Produksi}

Peneliti melakukan tiga kali tahapan, diawali dengan satu tahapan linear, lalu dua tahapan iterasi. Pada tahapan linear pertama, peneliti mematangkan konsep seperti pada Tabel 3. Rancangan alurflowchart dapat dilihat pada Gambar 3. 
Tabel 3 Rancangan Desain Permainan

\begin{tabular}{|c|c|}
\hline Desain & Deskripsi \\
\hline Genre & $\begin{array}{l}\text { Permainan ini bergenre arcade. Genre ini dipilih agar } \\
\text { dapat melatih pemain untuk mengingat pengetahuan } \\
\text { dasar yang ada terkait etiket perjamuan makan budaya } \\
\text { Barat. Permainan berbentuk kuis tanya-jawab dengan } \\
\text { pilihan ganda, dimana pemain harus memilih jawaban } \\
\text { yang benar untuk mendapat poin }\end{array}$ \\
\hline Alur & $\begin{array}{l}\text { Permainan ini berbentuk kuis tanya-jawab, sehingga } \\
\text { tidak ada karakter lain yang digunakan. Selama } \\
\text { menjawab pertanyaan, pemain akan mendapat tiga } \\
\text { pilihan bantuan yang masing-masing hanya dapat } \\
\text { digunakan sekali selama permainan, yaitu sebagai } \\
\text { berikut: } \\
\text { Menyerah, yaitu mengambil poin yang sudah dicapai } \\
\text { dari pertanyaan sebelumnya. Misalnya, jika pemain } \\
\text { menyerah pada pertanyaan keempat, maka ia akan } \\
\text { mendapat } 300 \text { poin yang merupakan total perolehan } \\
\text { poin dari tiga pertanyaan sebelumnya } \\
\text { 50:50, yaitu menyisakan dua kemungkinan jawaban } \\
\text { yang benar. Dua jawaban lainnya yang salah akan } \\
\text { dihilangkan dari layar } \\
\text { Bocoran, yaitu menunjukkan jawaban yang benar } \\
\text { dengan warna berbeda }\end{array}$ \\
\hline Tantangan & $\begin{array}{l}\text { Pemain dihadapkan dengan lima level titik aman yang } \\
\text { harus dicapai, dengan skala pertanyaan dari mudah ke } \\
\text { sulit. Titik aman level pertama bernilai } 0 \text { poin, level } \\
\text { kedua bernilai } 500 \text { poin, level ketiga bernilai } 1000 \text { poin, } \\
\text { level keempat bernilai } 1500 \text { poin, dan level kelima } 2000 \\
\text { poin. Setiap level terdiri dari lima pertanyaan, sehingga } \\
\text { total keseluruhan adalah } 25 \text { pertanyaan. Setiap } \\
\text { pertanyaan juga diberikan hitungan mundur selama } 20 \\
\text { detik. Jika pemain salah menjawab atau kehabisan } \\
\text { waktu menjawab di tengah permainan, pemain akan } \\
\text { mendapat poin sesuai level titik aman terakhir. } \\
\text { Misalkan, jika pemain sudah berhasil menjawab tiga } \\
\text { pertanyaan dan mendapat } 300 \text { poin, kemudian ia salah } \\
\text { menjawab pada pertanyaan keempat, maka poin yang ia } \\
\text { dapat adalah } 0 \text {. Jika pemain menjawab dengan benar, } \\
\text { maka ia mendapat } 100 \text { poin dari setiap pertanyaan. Jika } \\
\text { pemain berhasil menjawab semua pertanyaan dengan } \\
\text { benar, maka total poinnya adalah } 2500\end{array}$ \\
\hline Gameplay & $\begin{array}{l}\text { Tujuan dari permainan ini adalah memberikan edukasi } \\
\text { teori dasar tata sikap dan perilaku dalam etiket } \\
\text { perjamuan makan budaya Barat. Edukasi disajikan } \\
\text { dalam bentuk kuis yang dilengkapi teks dan gambar. } \\
\text { Pemain hanya perlu menjawab pertanyaan dengan benar } \\
\text { untuk mendapat poin sempurna. Selama permainan } \\
\text { berlangsung, pemain hanya perlu melakukan klik dari } \\
\text { mouse atau klik dengan sentuhan pada layar touchscreen }\end{array}$ \\
\hline $\begin{array}{l}\text { Faktor } \\
\text { Kemenarikan }\end{array}$ & $\begin{array}{l}\text { Tampilan yang digunakan untuk permainan edukasi ini } \\
\text { adalah jenis tampilan dua dimensi yang hanya terdiri } \\
\text { dari ukuran panjang dan lebar. Selama permainan } \\
\text { berlangsung, permainan akan menampilkan beberapa } \\
\text { ilustrasi gambar terkait pertanyaan terkini, seperti meja } \\
\text { makan, ruang perjamuan, makanan, atau minuman. } \\
\text { Level pemain akan ditampilkan dalam bentuk progress } \\
\text { bar dengan warna yang berbeda pada setiap level, yaitu } \\
\text { dengan urutan warna merah, kuning, hijau, biru, dan } \\
\text { ungu }\end{array}$ \\
\hline
\end{tabular}

Pada iterasi pertama, peneliti melakukan proses obfuscation dan pembatasan akses terhadap beberapa kombinasi tombol yang dapat digunakan untuk menduplikasi isi teks dan mengunduh gambar yang digunakan di dalam permainan. Peneliti juga menambahkan pertanyaan dan mengganti fungsi pengacakan pertanyaan dan jawaban. Terakhir, peneliti memperbaiki beberapa sistematika penulisan dan desain ukuran dari elemen progress bar.

Pada iterasi kedua, peneliti melakukan penambahan fitur bantuan Polling dengan menggunakan sistem basis data MySQL. Selain itu, peneliti juga menambahkan fitur pendukung, yaitu musik latar belakang dan efek suara ketika menekan tombol di dalam permainan. Fitur musik ditambahkan agar dapat menambah faktor kemenarikan dalam permainan.

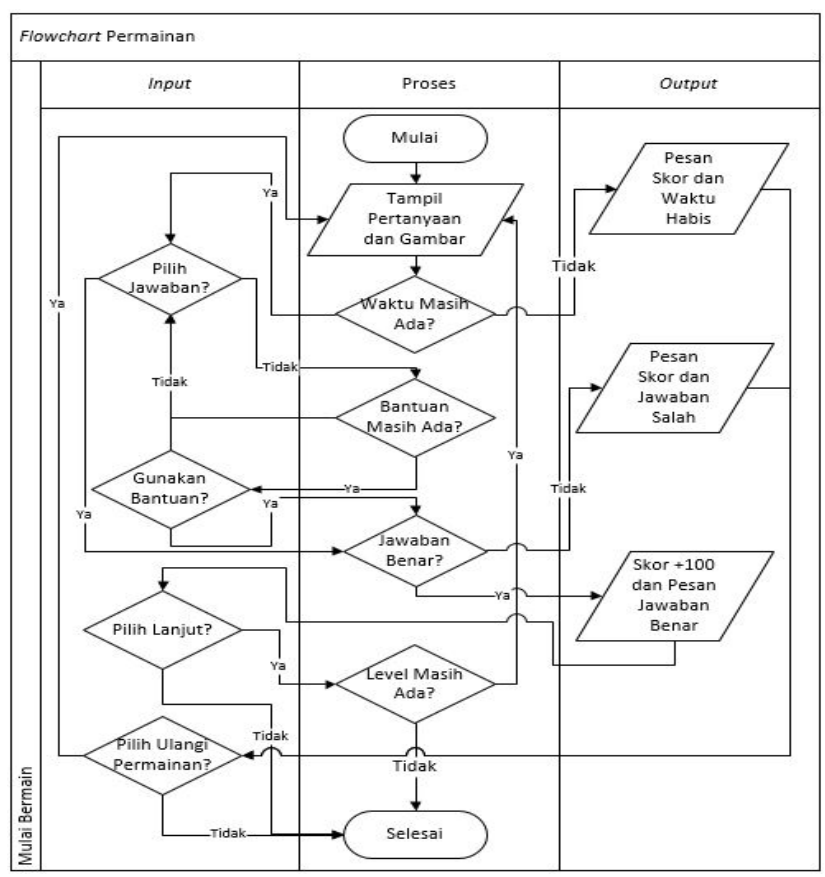

Gambar 3 Flowchart Permainan

\section{Produksi}

Pada tahapan linear pertama, peneliti membuat kode pemrograman untuk fungsi level, poin, waktu, pengacakan pertanyaan dan pilihan jawaban, bantuan Bocoran, 50:50, dan Menyerah. Pada iterasi pertama, peneliti melakukan proses obfuscation, membuat kode untuk membatasi akses kombinasi tombol developer mode, serta perbaikan terhadap penulisan dan desain. Pada iterasi kedua, peneliti menambahkan kode pemrograman untuk fungsi musik, efek suara, dan Polling yang terhubung dengan basis data MYSQL.

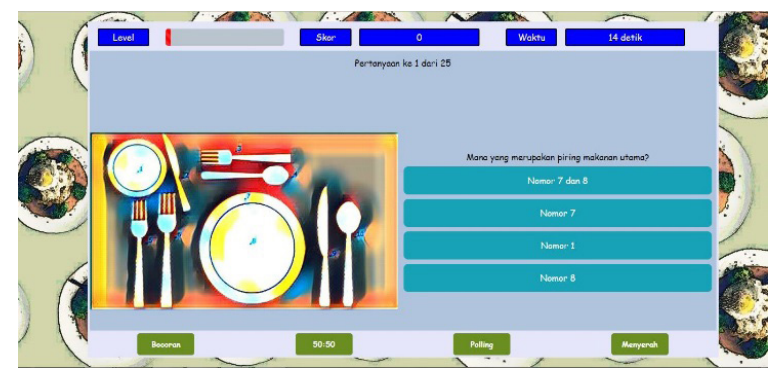

Gambar 4 Halaman Permainan Level 1

Ketika alamat situs pertama kali dibuka, halaman Home akan menampilkan 3 tombol. Tombol Mulai untuk memulai permainan. Tombol Bantuan untuk membaca teori singkat seputar etiket perjamuan makan serta intruksi permaian. Tombol Tentang untuk melihat informasi mengenai pihak pengembang. Jika pemain menekan tombol Mulai, pemain akan diarahkan ke halaman Game seperti pada Gambar 4. Pada panel atas terdapat kotak level, skor, dan hitungan mundur 20 detik untuk masing- 
masing pertanyaan. Skor awal untuk pertanyaan pertama di level 1 adalah 0. Pada panel selanjutnya terdapat pertanyaan, gambar, dan pilihan jawaban yang ditampilkan secara acak. Pada panel terakhir terdapat fitur bantuan, yaitu tombol Bocoran, 50:50, Polling, dan Menyerah, dimana masing-masing tombol hanya dapat digunakan sekali.

Permainan terbagi menjadi 5 level yang dibedakan dengan warna kotak level merah, kuning, hijau, biru, dan ungu. Masing-masing level terdiri dari 5 pertanyaan dengan skor titik aman yang berbeda. Skor titik aman di level 1 adalah 0 , level 2 adalah 500, level 3 adalah 1000, level 4 adalah 1500, dan level 5 adalah 2000 .

Jika pemain berhasil menjawab dengan benar, maka hitungan mundur dihentikan dan popup berisi pesan "Jawaban Benar" akan ditampilkan. Pemain harus menekan tombol Lanjut untuk melanjutkan ke pertanyaan selanjutnya. Setelah menekan tombol Lanjut, kotak level akan bertambah 1 dan skor akan ditambahkan 100. Hitungan mundur akan diulang kembali dari 20 detik. Tombol bantuan yang sudah dipakai akan dihilangkan.

Jika pemain salah menjawab atau kehabisan waktu sebelum menjawab, maka pemain akan mendapat skor di titik aman. Popup pesan "Jawaban Salah" atau "Waktu Habis" akan ditampilkan. Pemain dapat menekan tombol Ulangi Permainan untuk memulai kembali permainan dari level 1 pertanyaan 1 atau menekan tombol Menu untuk kembali ke halaman Home. Tombol bantuan yang sudah dihilangkan akan ditampilkan lagi ketika menekan tombol Ulangi Permainan.

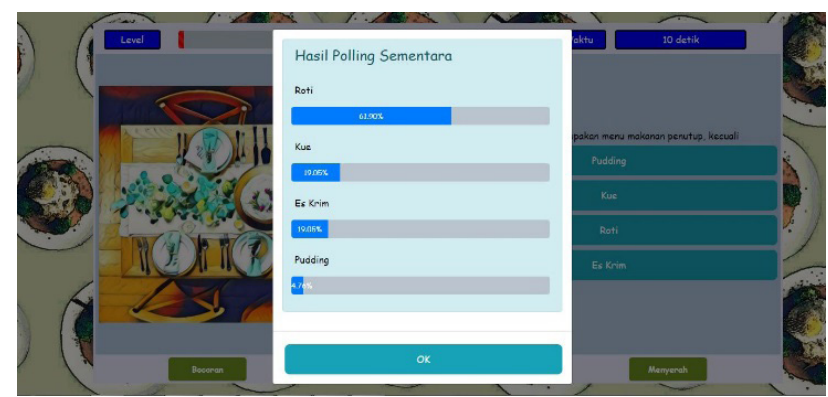

Gambar 5 Tampilan Bantuan Polling

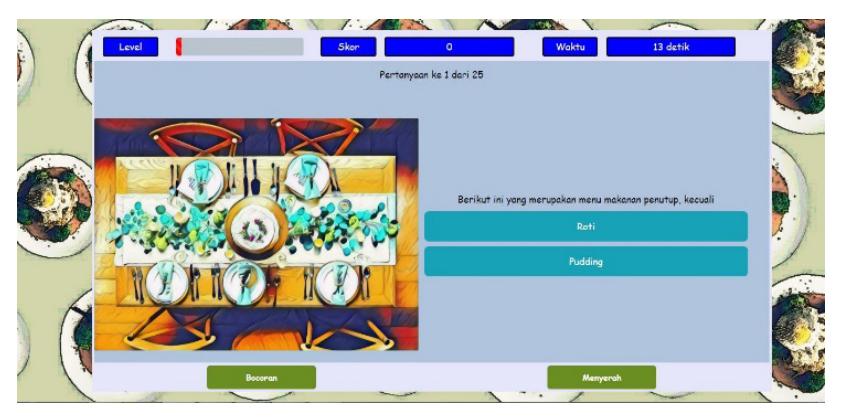

Gambar 6 Tampilan Bantuan 50:50
Jika pemain merasa kesulitan menjawab dan menggunakan tombol bantuan. Pemain dapat menggunakan lebih dari 1 bantuan untuk 1 pertanyaan. Jika pemain menekan tombol Polling, maka hasil persentase polling dari masing-masing pilihan jawaban akan ditampilkan di dalam dialog box seperti pada Gambar 5. Hasil tersebut diperoleh dari berapa kali pilihan jawaban dipilih oleh pemainpemain terdahulu. Tekan Ok untuk menutup dialog box tersebut. Jika ia menekan tombol 50:50, maka 2 pilihan jawaban yang salah akan dihilangkan, sehingga tersisa 2 kemungkinan pilihan jawaban yang benar seperti pada Gambar 6. Tombol 50:50 kemudian juga dihilangkan, sehingga menyisakan 2 tombol bantuan lain.

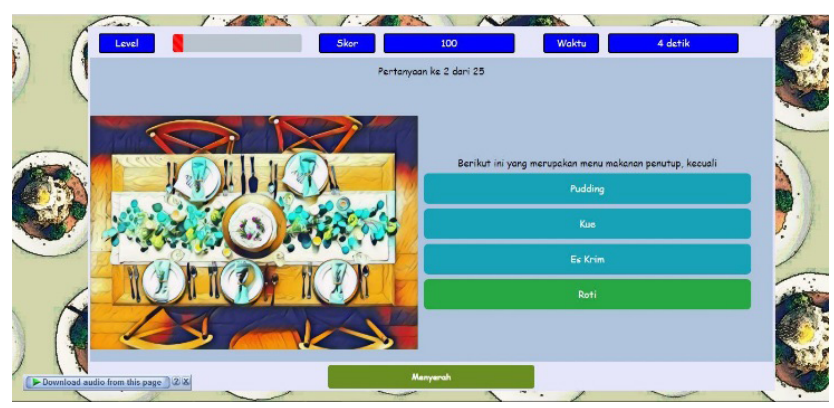

Gambar 7 Tampilan Bantuan Bocoran

Jika pemain sudah berhasil menjawab pertanyaan sebelumnya dengan benar dan sudah melanjutkan ke pertanyaan selanjutnya, maka tampilan panel skor dan level akan bertambah seperti pada Gambar 7. Bantuan yang tesisa saat ini adalah Bocoran dan Menyerah. Jika ia menekan tombol Bocoran seperti pada Gambar 7, maka pilihan jawaban yang benar akan diberikan warna hijau. Pilihan tersebut belum dikunci, sehingga pemain masih dapat memilih jawaban lain.

Jika pemain merasa masih tidak bisa menjawab pertanyaan dan tidak ingin bermain lagi, pemain dapat menekan tombol Menyerah. Jika menekan tombol menyerah, skor akhir akan ditampilkan. Misalnya jika pemain hanya berhasil menjawab 1 pertanyaan di level 1, maka skor akhirnya 100. Pemain dapat menekan tombol Ulangi Permainan untuk mengulang

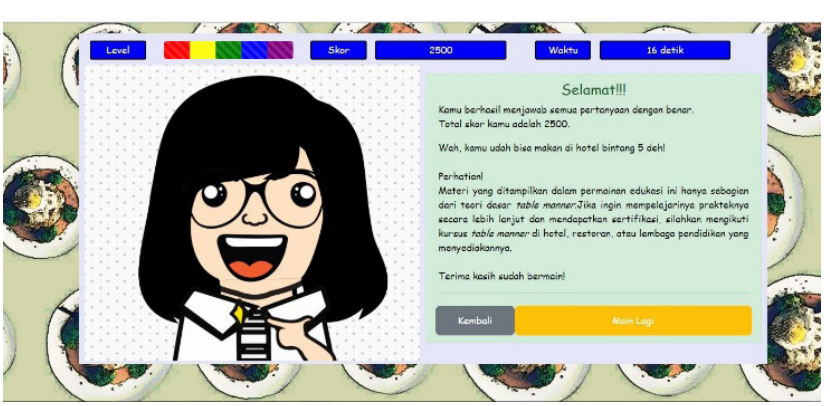

Gambar 8 Tampilan Akhir Permainan 
kembali permainan dari level 1 atau menekan tombol Menu untuk kembali ke halaman Home.

Jika pemain berhasil menyelesaikan semua pertanyaan dengan benar sampai dengan pertanyaan 5 di level 5, maka pesan seperti pada Gambar 8 akan ditampilkan. Kotak level akan terisi penuh dengan warna yang sesuai. Total skor akhir adalah 2500 . Hitungan waktu otomatis dihentikan. Pemain dapat menekan tombol Ulangi Permainan untuk mengulang permainan atau menekan tombol Menu untuk kembali ke halaman Home.

\section{E. Pengujian}

Peneliti melakukan pengujian secara black box. Hasil pengujian pertama, peneliti menemukan fungsi pengacakan jawaban yang masih belum efektif, skrip jawaban yang masih dapat terbaca, serta kesalahan dalam ukuran gambar dan penulisan, sehingga peneliti harus melakukan iterasi pertama. Pada iterasi pertama, peneliti mendapatkan hasil bahwa semua Tabel 4 Hasil Pengujian

\begin{tabular}{|c|c|c|}
\hline Fungsi & Indikator Kesuksesan & Hasil \\
\hline Tombol Mulai & $\begin{array}{l}\text { Masuk ke halaman permainan untuk } \\
\text { memulai permainan }\end{array}$ & Valid \\
\hline $\begin{array}{l}\text { Tombol } \\
\text { Bantuan }\end{array}$ & $\begin{array}{l}\text { Masuk ke halaman Bantuan untuk } \\
\text { melihat informasi terkait etiket } \\
\text { perjamuan makan }\end{array}$ & Valid \\
\hline $\begin{array}{l}\text { Tombol } \\
\text { Tentang }\end{array}$ & $\begin{array}{l}\text { Masuk ke halaman Tentang untuk } \\
\text { melihat informasi terkait pihak } \\
\text { pengembang }\end{array}$ & Valid \\
\hline $\begin{array}{l}\text { Tombol } \\
\text { Kembali }\end{array}$ & Masuk ke halaman utama & Valid \\
\hline Level & $\begin{array}{l}\text { Menampilkan level pertanyaan yang } \\
\text { sudah dilewati }\end{array}$ & Valid \\
\hline Poin & $\begin{array}{l}\text { Menampilkan poin pada akhir } \\
\text { permainan }\end{array}$ & Valid \\
\hline Waktu & $\begin{array}{l}\text { Menampilkan hitungan mundur pada } \\
\text { setiap pertanyaan }\end{array}$ & Valid \\
\hline $\begin{array}{l}\text { Pertanyaan, } \\
\text { Gambar dan } \\
\text { Pilihan } \\
\text { Jawaban }\end{array}$ & $\begin{array}{l}\text { Menampilkan pertanyaan, gambar, } \\
\text { dan pilihan jawaban secara acak yang } \\
\text { dapat dipilih untuk menentukkan } \\
\text { benar atau salah, lalu menampilkan } \\
\text { pertanyaan selanjutnya }\end{array}$ & Valid \\
\hline $\begin{array}{l}\text { Tombol } \\
\text { Bocoran }\end{array}$ & $\begin{array}{l}\text { Menunjukkan pilihan jawaban yang } \\
\text { benar dengan warna berbeda }\end{array}$ & Valid \\
\hline Tombol 50:50 & $\begin{array}{l}\text { Menunjukkan dua kemungkinan } \\
\text { pilihan jawaban yang benar dan } \\
\text { menghilangkan pilihan lain yang salah }\end{array}$ & Valid \\
\hline $\begin{array}{l}\text { Tombol } \\
\text { Menyerah }\end{array}$ & $\begin{array}{l}\text { Mengakhiri permainan dan } \\
\text { mengambil poin pada level terakhir } \\
\text { yang dicapai }\end{array}$ & Valid \\
\hline Responsif & $\begin{array}{l}\text { Membuat tampilan responsif di } \\
\text { berbagai ukuran layar }\end{array}$ & Valid \\
\hline $\begin{array}{l}\text { Fitur view } \\
\text { source }\end{array}$ & $\begin{array}{l}\text { Menyembunyikan fitur view source } \\
\text { melalui klik kanan dan kombinasi } \\
\text { tombol }\end{array}$ & Valid \\
\hline Obfuscation & $\begin{array}{l}\text { Meng-obfuscate skrip Javascript, } \\
\text { sehingga sulit dibaca ketika membuka } \\
\text { view source }\end{array}$ & Valid \\
\hline $\begin{array}{l}\text { Akses } \\
\text { kombinasi } \\
\text { tombol }\end{array}$ & $\begin{array}{l}\text { Membatasi beberapa akses kombinasi } \\
\text { tombol untuk menduplikasi dan } \\
\text { menempel elemen teks atau gambar } \\
\text { dari atau ke halaman }\end{array}$ & Valid \\
\hline $\begin{array}{l}\text { Efek suara dan } \\
\text { musik }\end{array}$ & $\begin{array}{l}\text { Memutar lagu di latar belakang dan } \\
\text { efek suara selama permainan }\end{array}$ & Valid \\
\hline $\begin{array}{l}\text { Tombol } \\
\text { Polling }\end{array}$ & $\begin{array}{l}\text { Menampilkan hasil polling dari setiap } \\
\text { pilihan jawaban }\end{array}$ & Valid \\
\hline
\end{tabular}

fungsi sudah berjalan dengan benar, lalu peneliti melakukan fase beta. Pada pengujian di iterasi kedua, semua fungsi beserta penambahannya sudah berjalan dengan benar. Penjelasan yang lebih lengkap terkait fungsionalitas yang sudah dibuat dapat dibaca pada Tabel 4.

Selama proses pengujian, peneliti menemukan beberapa masalah yang menjadi titik perhatian selama pengembangan berlangsung. Penjelasan mengenai beberapa temuan selama penelitian dapat dibaca pada Tabel 5. Hampir semua masalah tersebut sudah mampu diatasi, kecuali masalah pada aplikasi Tabel 5 Hasil Temuan Pengujian

\begin{tabular}{|c|c|}
\hline Hasil Temuan & Cara Mengatasi \\
\hline $\begin{array}{l}\text { Skrip yang masih } \\
\text { dapat diakses } \\
\text { melalui fitur view } \\
\text { source dan beberapa } \\
\text { akses kombinasi } \\
\text { tombol }\end{array}$ & $\begin{array}{l}\text { Melakukan proses obfuscation setelah } \\
\text { semua kode Javascript selesai dibuat. } \\
\text { Obfuscation dilakukan dengan } \\
\text { menggunakan online tools. Peneliti juga } \\
\text { melakukan pembatasan akses terhadap } \\
\text { beberapa kombinasi tombol yang dapat } \\
\text { digunakan untuk menduplikasi isi teks } \\
\text { dan mengunduh gambar yang digunakan } \\
\text { di dalam permainan }\end{array}$ \\
\hline $\begin{array}{l}\text { Proses pengacakan } \\
\text { pertanyaan dan } \\
\text { jawaban dengan } \\
\text { fungsi } \\
\text { Math.random() } \\
\text { belum efektif, } \\
\text { karena persentase } \\
\text { kemunculan urutan } \\
\text { indeks array awal } \\
\text { lebih besar daripada } \\
\text { indeks selanjutnya }\end{array}$ & $\begin{array}{l}\text { Menambahkan jumlah pertanyaan dari } \\
\text { yang semula } 25 \text { menjadi } 35 \text {, namun } \\
\text { jumlah yang ditampilkan ke pemain tetap } \\
25 \text { pertanyaan. Ketika pertanyaan } \\
\text { ditambahkan dan fungsi pengacakan } \\
\text { masih tetap sama, persentase } \\
\text { kemunculan } 5 \text { indeks array awal masih } \\
\text { lebih besar daripada } 2 \text { indeks akhir. } \\
\text { Fungsi pengacakan akhirnya diubah } \\
\text { dengan menggunakan teknik bubble sort, } \\
\text { sehingga persentase kemunculan masing- } \\
\text { masing indeks merata }\end{array}$ \\
\hline $\begin{array}{l}\text { Tampilan pada } \\
\text { Internet Explorer } \\
\text { berbeda dengan } \\
\text { tampilan pada } \\
\text { aplikasi peramban } \\
\text { lain }\end{array}$ & $\begin{array}{l}\text { Menambahkan trik media screen CSS } \\
\text { Hacks pada file bootstrap.css. Pada baris } \\
\text { kode tersebut, peneliti memberikan } \\
\text { beberapa ukuran dan tata letak yang } \\
\text { berbeda untuk beberapa elemen yang } \\
\text { memiliki tampilan yang berbeda dari } \\
\text { aplikasi lain }\end{array}$ \\
\hline $\begin{array}{l}\text { Internet Explorer } \\
\text { tidak mendukung } \\
\text { jenis file audio .mp3 } \\
\text { dan Opera tidak } \\
\text { mendukung .wav }\end{array}$ & $\begin{array}{l}\text { Menambahkan versi semua file audio } \\
\text { yang sudah dikonversi dari .mp3 menjadi } \\
\text {.wav dan sebaliknya. Peneliti } \\
\text { menambahkan fungsi pengecekan jenis } \\
\text { aplikasi peramban di dalam file } \\
\text { Javascript agar Javascript dapat } \\
\text { mengeksekusi jenis file yang sesuai }\end{array}$ \\
\hline $\begin{array}{l}\text { Internet Explorer } \\
\text { versi } 7 \text { ke bawah } \\
\text { tidak mendukung } \\
\text { nama objek AJAX } \\
\text { terkini }\end{array}$ & $\begin{array}{l}\text { Menambahkan fungsi pengecekan jenis } \\
\text { aplikasi peramban di dalam file } \\
\text { Javascript, dimana IE versi } 7 \text { ke bawah } \\
\text { harus menggunakan nama objek } \\
\text { ActiveXObject }\end{array}$ \\
\hline $\begin{array}{l}\text { Safari versi } \\
\text { Windows tidak } \\
\text { dapat menampilkan } \\
\text { panel permaian }\end{array}$ & $\begin{array}{l}\text { Peneliti telah melakukan riset dengan } \\
\text { membaca ulang dokumentasi Bootstrap } \\
\text { pada situs resminya. Hasilnya, Bootstrap } \\
\text { menyatakan bahwa aplikasi peramban } \\
\text { Safari versi Windows tidak mendukung } \\
\text { tag Bootstrap terbaru. Selain itu, Safari } \\
\text { versi Windows juga sudah tidak } \\
\text { didukung oleh Apple, Inc. }\end{array}$ \\
\hline $\begin{array}{l}\text { Tampilan pada } \\
\text { aplikasi peramban } \\
\text { proxy di sistem } \\
\text { operasi Android } \\
\text { berbeda dengan } \\
\text { tampilan pada } \\
\text { aplikasi peramban } \\
\text { lain }\end{array}$ & $\begin{array}{l}\text { Peneliti melakukan riset dengan } \\
\text { membaca ulang dokumentasi Bootstrap } \\
\text { pada situs resminya. Hasilnya, Bootstrap } \\
\text { menyatakan bahwa aplikasi proxy tidak } \\
\text { didukung oleh versi terbaru Bootstrap, } \\
\text { sehingga disarankan untuk membuka } \\
\text { web dari aplikasi peramban yang sering } \\
\text { digunakan, seperti Chrome, Firefox, } \\
\text { Edge, IE v10+, Opera, dll. Aplikasi } \\
\text { tersebut harus dalam versi terbaru }\end{array}$ \\
\hline
\end{tabular}


peramban Safari versi Windows dan proxy. Bootstrap tidak mendukung jenis aplikasi tersebut, sehingga peneliti hanya dapat menyarankan pemain untuk menggunakan jenis aplikasi peramban yang lain seperti pada Tabel 2.

\section{F. Beta}

Proses pengujian ini dilakukan sebanyak dua kali, karena peneliti sempat melakukan dua iterasi. Pada tahap iterasi pertama, peneliti berhasil mengumpulkan pendapat dari 10 orang penguji. Pada tahap iterasi kedua, peneliti hanya berhasil mengumpulkan pendapat dari 15 orang penguji. Pengujian dilakukan dengan menggunakan pertanyaan terbuka dalam bentuk essay, dimana peneliti menggunakan pertanyaan yang sama untuk kedua proses pengujian. Iterasi pertama dilakukan dengan close beta testing, sementara iterasi kedua dilakukan dengan open beta testing.

Peneliti memberikan lima pertanyaan. Pertanyaan pertama menanyakan "Apakah permainan ini dapat membantu Anda dalam mempelajari etiket perjamuan makan formal ala Barat?". Sebagian besar penguji mengatakan bahwa mereka belum pernah mempelajari mengenai etiket ini. Lalu setelah disimpulkan dari hasil jawaban mereka, permainan ini dapat membantu penguji dalam mempelajari etiket perjamuan makan budaya Barat dengan lebih mudah.

Pertanyaan kedua menanyakan "Apa hal yang Anda sukai dari permainan ini, baik dari segi tampilan, genre, alur, dan fitur?". Berdasarkan hasil yang didapat, sebagian besar penguji menyukai alur permainan dan materi yang disajikan. Mereka mengatakan bahwa alur permainan menarik. Materi yang disajikan juga mudah dipelajari dengan adanya ilustrasi gambar pelengkap.

Pertanyaan ketiga menanyakan "Apakah ada kendala yang terjadi saat memainkan permainan ini? Misalnya, seperti tombol yang tidak merespon dengan benar.”. Berdasarkan hasil yang didapat, sebagian besar menyatakan bahwa fungsionalitas tombol dan tampilan sudah berjalan dengan sesuai. Kendala yang sering terjadi hanya waktu respon yang lama akibat gangguan sinyal ketika mengakses web.

Pertanyaan keempat menanyakan "Adakah fitur yang menurut Anda kurang begitu diperlukan atau tidak sesuai dengan alur permainan ini?". Berdasarkan hasil yang didapat, sebagian besar menyatakan bahwa semua fitur diperlukan. Namun, terdapat beberapa orang yang menyarankan untuk mengganti beberapa nama tombol yang dianggap agak aneh di dalam bahasa Indonesia.

\section{G. Rilis}

Permainan dapat diakses pada alamat situs http:// tablemannersgame.000webhostapp.com. Pengguna dapat mengaksesnya dari berbagai perangkat, namun disarankan menggunakan perangkat dan aplikasi peramban seperti pada Tabel 2 .

\section{SIMPULAN}

Permainan edukasi yang dihasilkan adalah permainan etiket perjamuan makan budaya Barat berbasis web yang berbentuk kuis tanya-jawab dengan genre arcade. Hasil akhir dari permainan ini dapat diakses pada alamat situs http:// tablemannersgame.000webhostapp.com. Aplikasi peramban yang disarankan untuk memainkan permainan ini dapat dilihat pada Tabel 2. Permainan dikembangkan dengan metode GDLC dan pemodelan prototipe. Peneliti hanya melakukan dua proses iterasi pada tahap pra produksi sampai tahap beta, karena sebagian requirement yang diperlukan sudah dipenuhi dan adanya keterbatasan waktu.

Peneliti melakukan proses obfuscation string berupa teks, nama fungsi, dan nama metode yang diubah menjadi bilangan UTF-8, sehingga tidak akan mudah dibaca melalui fitur view source. Tools obfuscator online digunakan untuk mempersingkat waktu konversi jika dibandingkan dengan cara manual. Hasil pengujian terhadap pengguna, pengguna merasa permainan ini dapat membantu mereka dalam mempelajari etiket dengan lebih mudah. Kekurangan permainan ini adalah desain gambar yang kurang menarik dan kurangnya varian fitur bantuan.

\section{DAFTAR RUJUKAN}

[1] P. Post and P. Senning, Emily Post's Table Manners for Kids, New York: Harper Collins e-book, 2009, pp. 7-49.

[2] B. Bertholon, S. Varrete and P. Bouvry, "JShadObf: A Javascript Obfuscator Based on Multi-Object Optimation Algorithm," in 7th International Conference, NSS, Madrid, 2013.

[3] E. Adams, Fundamentals of Game Design, 3rd ed., San Fransisco: New Rider, 2014, pp. 67-78.

[4] A. F. Anggraini, N. Erviana, S. Anggraini and D. D. Prasetya, "Aplikasi Game Edukasi Petualangan Nusantara," in Prosiding SENTIA 2016 - Politeknik Negeri Malang, Malang, 2016.

[5] R. Adiwikarta and H. B. Dirgantara, "Pengembangan 
Permainan Video Endless Running Berbasis Android Menggunakan Framework Game Development Life Cycle," in KALBIScientia, DKI Jakarta, 2017.

[6] E. Budiman, R. Hasudungan and A. Khoiri, "Online Game "Pics and Words" Sebagai Media Edukasi Bahasa Inggris Berbasis HTML," in Prosiding Seminar Ilmu Komputer dan Teknologi Informasi, Samarinda, 2017.

[7] D. Gosselin, Principles of HTML, XHTML, and DHTML, Cengage Learning, 2010, pp. 1-10, 849-852.

[8] R. R. Rerung, Pemrograman Web Dasar, 1st ed., Yogyakarta: Depublish/CV Budi Utama, 2018, pp. 133-138, 156-158.

[9] E. Quigley, Javascript by Example, 2nd ed., Pearson Education Ltd, 2004, pp. 1-3, 151, 254-263.

[10] M. R. Faizal, Seri Pemrograman Pengenalan jQuery untuk Pemula, Indonesia Net Developer Community.
[11] M. Lambert, Learning Bootstrap 4, 2nd ed., Birmingham: Packt Publishing Ltd., 2016, pp. 7-12.

[12] A. Kadir, Konsep \& Tuntunan Praktis Basis Data, Yogyakarta: ANDI, 2002, pp. 7-13, 101-104.

[13] A. Zaki, 36 Menit Belajar Komputer PHP dan MySQL, Jakarta: PT Elex Media Komputindo, 2008, pp. 94-96.

[14] H. B. Dirgantara and T. Marselino, "Development of Web-based Matrix Operations Calculation as a Learning Media,” in IJNMT, Jakarta, 2017.

[15] R. Ramadan and Y. Widyani, "Game Development Life Cycle Guidelines," in ICACSIS, Bandung, 2013.

[16] S. Desikan and G. Ramesh, Software Testing: Principles and Practices, 6th ed., P. H. N. Mahabala, Ed., New Delhi: Dorling Kindersky (India) Pvt Ltd., 2008, pp. 74-83. 